\title{
Europa in Vlaanderen: een verkennende analyse van de impact van Europese integratie op Vlaamse politieke partijen
}

Gilles Pittoors, Wouter Wolfs, Steven Van Hecke en Peter Bursens

ABSTRACT: Europe in Flanders: An exploratory study of the impact of European integration on Flemish political parties

This article discusses the Europeanisation of Flemish political parties. Based on a dataset spanning the period 1999-2014, the article assesses whether the increase in EU salience at the level of the party (elites) after 2010 resulted in increased Europeanisation, defined as the increased mentioning of the EU in party programmes (i.e. programmatic Europeanisation) and the incorporation of the EU in political party structures (i.e. organisational Europeanisation). Our empirical analysis shows that salience does not adequately explain the level of Europeanisation. Rather, the ideological position of parties seems to provide for a stronger case. The findings therefore call for more in-depth research on intervening variables in order to better explain the varying Europeanisation of (Flemish) political parties.

Keywords: Europeanisation, political parties, party organisation, party programmes, Flanders, Belgium

\section{Inleiding}

Dit artikel bestudeert de europeanisering van de Vlaamse politieke partijen in twee cruciale domeinen: partijprogramma's en interne partijorganisatie. Hiermee beoogt dit artikel een hiaat in onze kennis weg te werken, aangezien noch de literatuur over de europeanisering van België, noch de bredere literatuur over de Belgische politieke partijen uitgebreid aandacht schenkt aan de europeanisering van Vlaamse 
politieke partijen. Toch zijn België en Vlaanderen door de aanhoudende constitutionele hervormingen, die veel aandacht vragen van de politieke elites, en de brede pro-Europese consensus interessante empirische cases. Politieke partijen zijn bovendien sleutelactoren in het Belgische politieke systeem, dat vaak omschreven wordt als een particratie (Deschouwer, 2009; Dumont \& De Winter, 2006). We kunnen verwachten dat politieke partijen meer impact zullen ondervinden van de Europese Unie (EU) naarmate integratie vordert (Ladrech, 2002): wanneer het Europese niveau bevoegd wordt voor meer beleidsdomeinen, zullen politieke partijen zich aanpassen. Hierbij is wel de salience van de EU als politieke kwestie bepalend: partijen en de partijleiding moeten voldoende belang hechten aan de EU vooraleer ze erop zullen reageren, i.e. er concrete gevolgen aan geven in hun positiebepaling en werking. Verschillende auteurs (Mair, 2000; Dardanelli, 2011; Carter et al., 2007) stellen dat de Vlaamse partijen tot 2010 een zeer gering belang aan de EU hechtten. Na 2010 stijgt die aandacht. Het doel van dit artikel is om te zien of die stijging zich vertaalt in enerzijds een bredere opname van de EU in de partijprogramma's en anderzijds een diepere incorporatie van de EU in de partijorganisatie. Om variatie tussen partijen te verklaren, kijkt dit artikel bovendien naar verschillen in ideologische positie vis-à-vis de EU.

Empirisch focust dit artikel op aanpassingen in de interne organisatie van partijen en de partijprogramma's in de periode van 1999 tot 2014. Data komen uit partijprogramma's, partijstatuten, interviews en een survey. Het artikel is opgedeeld in vier delen. Ten eerste schetsen we beknopt de literatuur over de europeanisering van politieke partijen; dat zal dienen als raamwerk voor de analyse. In een tweede deel gaan we dieper in op de methode, de dataverzameling en de hypothesen. Ten derde testen we de hypothesen en presenteren we de resultaten van de analyse. Ten slotte trekken we conclusies over de impact van de Europese integratie op de Vlaamse politieke partijen, alsook over de stappen voor verder onderzoek.

\section{Dimensies van europeanisering van politieke partijen}

Sinds het einde van de jaren negentig van de vorige eeuw is de academische literatuur over europeanisering aanzienlijk gegroeid. Begonnen als 'spin-off' van de grote theorieën van Europese integratie (Bulmer, 2006), focusten de eerste studies voornamelijk op de brede gevolgen van Europese integratie op het (sub)nationale niveau. Toch bleef een consensus over een overkoepelende definitie uit. Verschillende definities werden en worden door elkaar gebruikt. Een zeer brede definitie is bijvoorbeeld die van Olsen, die stelt dat je europeanisering vanuit verschillende 
hoeken kunt bekijken: van de transformatie van de grenzen van Europa, tot de penetratie van Europa in nationale politieke systemen (Olsen, in: Carter, Luther, \& Poguntke, 2007, p. 3). Ladrech is iets specifieker in zijn definitie en stelt dat europeanisering een incrementeel proces is dat de richting en vorm van politiek aanpast tot op het punt dat Europese politieke en economische dynamieken deel worden van de logica van nationale politiek en beleidsvorming (Ladrech, in: Carter et al., 2007, p. 5, eigen vertaling). Die laatste definitie wordt in dit artikel gebruikt.

Hoewel het onderzoek naar europeanisering een breed toepassingsveld kent, wordt pas recent specifieke aandacht besteed aan de europeanisering van politieke partijen. De Europese politieke en economische dynamieken kunnen politieke partijen op verschillende manieren beïnvloeden. Twee auteurs in het bijzonder zijn toonaangevend geweest voor de theoretisering van europeanisering van partijen. Mair (2007) ontwikkelde een classificatie van de manieren waarop de EU een invloed kan hebben op partijen en partijsystemen. Hierbij identificeert hij twee mechanismen van europeanisering: penetratie van de EU in nationale partijen en partijsystemen, en institutionalisering van politieke dynamieken op EU-niveau. Die mechanismen kunnen volgens Mair zowel een directe als een indirecte impact hebben, waardoor hij tot vier mogelijke dimensies van europeanisering van politieke partijen komt (zie Tabel 1).

\section{TABEL 1. De vier dimensies van europeanisering van Mair.}

\begin{tabular}{llll}
\hline & \multicolumn{2}{c}{ Mechanisme } \\
\hline Impact & \multicolumn{1}{c}{ Penetratie } & \multicolumn{1}{c}{ Institutionalisering } \\
\hline & $\begin{array}{l}\text { (1) Ontstaan van nieuwe euroscepti- } \\
\text { sche partijen; incorporatie van de EU in } \\
\text { bestaande partijen }\end{array}$ & $\begin{array}{l}\text { (2) Ontstaan en consolidatie van een } \\
\text { pan-Europees partijsysteem }\end{array}$ \\
\hline Indirect & $\begin{array}{l}\text { (3) Uitholling en devaluatie van natio- } \\
\text { nale partijcompetitie }\end{array}$ & $\begin{array}{l}\text { (4) Ontstaan van alternatieve represen- } \\
\text { tatiekanalen los van partijen }\end{array}$ \\
\hline
\end{tabular}

Bron: Mair, 2007, p. 157.

Ladrech (2002) ontwikkelde een analytisch raamwerk met vijf arena's waarin hij een europeanisering van nationale politieke partijen verwacht: partijprogramma's, partijorganisatie, partijcompetitie, de relatie tussen partijen en de regering, en de relaties tussen partijen over de nationale grenzen heen.

Verscheidene auteurs hebben die dimensies verder uitgewerkt en empirisch getoetst. Wat de europeanisering van de partijorganisatie betreft, ontwikkelde Raunio (2002) een model om te beschrijven hoe en in welke omstandigheden Europese integratie de autonomie van de partijleiding versterkt. Carter et al. (2007) verrichtten een van de eerste grote vergelijkende empirische studies op dat vlak, waarbij zij focusten op veranderingen in de organisatie van politieke partijen en de positie 
van de partijleiding. Pennings (2006) onderzocht de europeanisering van partijprogramma's tussen 1960 en 2003 van de belangrijkste nationale partijen in de toenmalige lidstaten. De Vries $(2007 ; 2010)$ ging dieper in op de derde dimensie van Ladrech (partijcompetitie) en analyseerde de politisering van de EU in de nationale verkiezingen in het Verenigd Koninkrijk, Denemarken, Nederland en Duitsland tussen 1992 en 2002. Andere auteurs maakten casestudies over de relaties van partijen over de nationale grenzen heen (Sloam, 2004; Hecke, 2009).

Onderzoek naar de europeanisering van Vlaamse politieke partijen is echter schaars. Het eerste verkennend onderzoek is gedaan door Deschouwer en Van Assche (2003). Zij concluderen op basis van een analyse van de partijstatuten dat Europese integratie een brede invloed heeft gehad op de formele organisatie van Vlaamse partijen (Deschouwer \& Van Assche, 2003, p. 140). Later onderzocht Dardanelli (2012) de link tussen de federalisering en de europeanisering van België, maar hij kwam tot de conclusie dat er slechts een beperkte europeanisering te bespeuren valt en dat de impact van de EU relatief stabiel is gebleven tussen 1968 en 2010. Ook bleek de mate van aandacht voor Europa sterk te verschillen van partij tot partij.

Dit artikel wil de bovenstaande empirische analyses verder aanvullen. Hierbij leggen we de nadruk op Mairs eerste dimensie van europeanisering: de directe penetratie van de EU in nationale partijen (Tabel 1). We zullen nagaan op welke manier de Vlaamse partijen de EU hebben geïncorporeerd. Met andere woorden: we kijken niet naar de europeanisering van het nationale partijsysteem, maar van de partijen zelf. Daarbij focussen we op de twee overeenkomstige arena's uit het raamwerk van Ladrech. Enerzijds verwijzen we naar de opname van de EU als thema in de programma's: hoe meer de EU opgenomen wordt, hoe meer we kunnen spreken van programmatische europeanisering. Anderzijds onderzoeken we de incorporatie in partijstructuren van zogenaamde 'EU-specialisten', i.e. zij die enkel of vooral over de EU werken (Ladrech, 2007, p. 5). Concreet zijn dat de Europarlementsleden van de partij en de EU-experts die actief zijn in de studiedienst of partijwerkgroepen. Hoe meer die specialisten een centrale functie in de partijstructuren hebben, hoe meer we kunnen spreken van organisatorische europeanisering.

\section{Het mechanisme van de europeanisering van politieke partijen}

Wat kunnen we verwachten omtrent de europeanisering van Vlaamse partijen? We verwachten in de eerste plaats dat de EU niet alle partijen in dezelfde mate zal beïnvloeden. Carter et al. (2007) en Ladrech (2012) stellen dat de mate waarin de 
EU een impact zal hebben op nationale partijen, afhangt van haar impact op de primaire doelen van die partijen. Naast de drie standaarddoelen - beleid, regeringsdeelname en stemmen - identificeert Ladrech nog een vierde: interne cohesie van de partij (Ladrech, 2012). Andere auteurs nemen min of meer een gelijkaardige benadering. Marks en Hooghe (2009) stellen dat de interne cohesie en de congruentie tussen partijen en electoraat twee belangrijke factoren zijn om europeanisering te verklaren. Ook in het onderzoek van Pennings (2006) naar de europeanisering van partijprogramma's komen de houding van de partij tegenover Europese integratie en de mate van interne partijconsensus over Europese integratie naar voren als belangrijke verklarende factoren voor de mate van europeanisering.

Wat de regeringsdeelname en interne cohesie betreft, zien we dat die van minder belang zijn voor de Vlaamse case. Ten eerste heeft de EU sowieso slechts een beperkte invloed op de regeringsvorming en het verdelen van politieke functies op nationaal niveau. Ten tweede zijn de Vlaamse partijen overweldigend cohesief wat de EU betreft (Grafiek 1), hoewel de EU een zeer verdelende factor kan zijn die heuse crises met zich mee kan brengen, zoals de geschiedenis van de Britse Conservatieven ons toont. Daarom zullen we ons in dit artikel toespitsen op het beleid en het behalen van stemmen als primaire doelen voor politieke partijen.

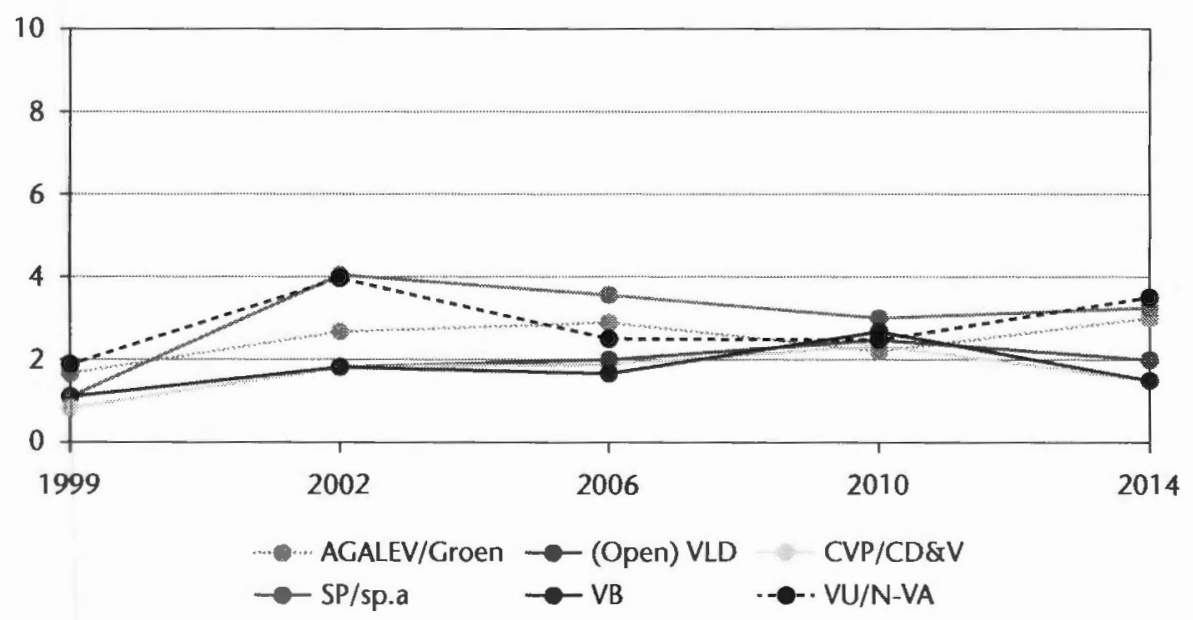

GRAFIEK 1. Onenigheid over de EU binnen de Vlaamse partijen (CHES-data)ำ.

Vanuit het perspectief van het beleid als doel kunnen we verwachten dat naarmate het belang van Europa als beleidsniveau toeneemt, de impact op het nationale niveau groter wordt en de partijen zich hieraan zullen aanpassen (Ladrech, 2002, p. 395). Dat groeiende belang van het Europese niveau is duidelijk merkbaar. Sinds het Verdrag van Maastricht van 1992 is de impact van de Europese integratie im- 
mers in snel tempo voelbaarder geworden voor de lidstaten. Niet alleen nam de Europese Centrale Bank het monetaire beleid van de Eurolanden over, de Europese instellingen kregen ook ruimere bevoegdheden op het vlak van bijvoorbeeld justitie en binnenlandse zaken (Dinan, 2010). Vanuit dat standpunt kunnen we een sterke stijging in europeanisering verwachten sinds de jaren 1990. Niet alleen zullen partijen steeds meer naar de EU verwijzen in hun partijprogramma's, ze zullen ook meer nood hebben aan expertise omtrent de EU, wat kan leiden tot een interne reorganisatie.

Ook de studie van Marks en Hooghe wijst in die richting. Zij stelden dat de verdieping en de uitbreiding van de EU ervoor heeft gezorgd, dat de "permissive consensus' onder de bevolking, waarbij burgers hetzij een positieve, hetzij een ongeïnteresseerde houding hadden tegenover Europese integratie (Hix \& Hoyland, 2011, p. 107), is vervangen door een 'constraining dissensus' waarbij de burgers verdeeld zijn over de EU en politieke elites niet langer vrij spel geven (Marks \& Hooghe, 2009). De bevinding dat de EU steeds belangrijker wordt op de politieke agenda tijdens de jaren 1990, wordt ook door andere studies bevestigd (Kriesi, 2007; Benoit \& Laver, 2006).

Toch noteren verscheidene auteurs dat de europeanisering van partijen en partijsystemen vrij beperkt is gebleven. Mair (2000) argumenteert hierbij dat het gebrek aan een partijsysteem op EU-niveau ervoor zorgt dat nationale partijen geen baat hebben bij noch dwang voelen om te reageren op de Europese integratie. De pro-EU-consensus en het gebrek aan politisering van de EU als politiek thema binnen de partijen stonden de europeanisering in de weg. Raunio (2000) focust meer op de interne partijstructuren, maar komt grotendeels tot dezelfde conclusie. Hij concludeert dat Europarlementsleden wel een sterkere positie in de partij krijgen naarmate de macht van het Europees Parlement groter wordt, maar dat partijen pas echt gaan reageren op Europese dossiers wanneer het belangrijk wordt voor de nationale arena. In dezelfde zin vinden ook Carter et al. (2007) slechts een beperkte europeanisering van partijen in het begin van de jaren 2000.

Als belangrijke verklarende factor voor die beperkte europeanisering wijzen deze auteurs op de lage salience van de EU, gezien als het belang dat partijen aan het EU-thema hechten. Ook verschillende andere auteurs benadrukten dat het belang van een thema voor een partij een sine qua non is om aanpassingen van de partij te veroorzaken (Carmines \& Stimson, 1986; Vries, 2007; Green-Pedersen, 2012; Marks \& Hooghe, 2009; Eijk \& Franklin, 2004). De salience-factor lijkt ook voor de Vlaamse case van groot belang. De Vlaamse partijen bewegen zich in de context van een atypisch partijsysteem, wat een gevolg is van het lange proces van staatshervorming. Door het langdurige proces van staatshervorming schonken partijen en vooral partijelites disproportioneel veel aandacht aan de binnenlandse constitutionele agenda, waarbij er amper tijd en ruimte was voor andere thema's, zoals de EU. 
Toch zijn er verschillende indicatoren die aangeven dat de aandacht voor de $\mathrm{EU}$, i.e. het politieke belang dat de Vlaamse partijelities hechten aan de EU, in het voorbije decennium groter is geworden. Grafiek 2 toont het belang van de EU voor de Vlaamse partijen. We zien dat voor de meeste Vlaamse partijen de EU fel aan belang heeft gewonnen in de periode 2010-2014, na een lange periode van zeer beperkte aandacht. Hoewel het belang van de EU voor de Vlaamse politieke partijen nog steeds eerder matig wordt ingeschat - geen enkele partij scoort meer dan 5/10 - zien we voor sommige partijen toch een aanzienlijke toename. Het doel van dit artikel is nagaan in welke mate die toegenomen aandacht zich weerspiegeld heeft in de europeanisering van de Vlaamse partijprogramma's en partijorganisatie.

Afgaand op voorgaand onderzoek (Mair, 2000; Carter et al., 2007), waarbij het gebrek aan politiek belang naar boven kwam als belangrijke verklarende factor voor het uitblijven van europeanisering, kunnen we dus verwachten dat na 2010 de europeanisering zal stijgen. Met andere woorden: door de stijging in het belang van de EU als beleidsniveau voor de Vlaamse politieke partijen kunnen we verwachten dat dit zich zal vertalen in een toename van enerzijds programmatische en anderzijds organisatorische europeanisering. Het argument dat de stijging te maken heeft met de verkiezingen voor het Europees Parlement in 2014, gaat slechts ten dele op, aangezien ook in 1999 samenvallende verkiezingen plaatsvonden en het belang in dat jaar lager werd ingeschat. Het sleuteljaar hierin is 2010. Op die basis kunnen we de volgende algemene hypothese stellen:

H1. De stijging van het belang dat partijen en partijelites hechten aan de EU sinds 2010 , leidt tot een stijging van de programmatische en organisatorische europeanisering van de Vlaamse partijen.

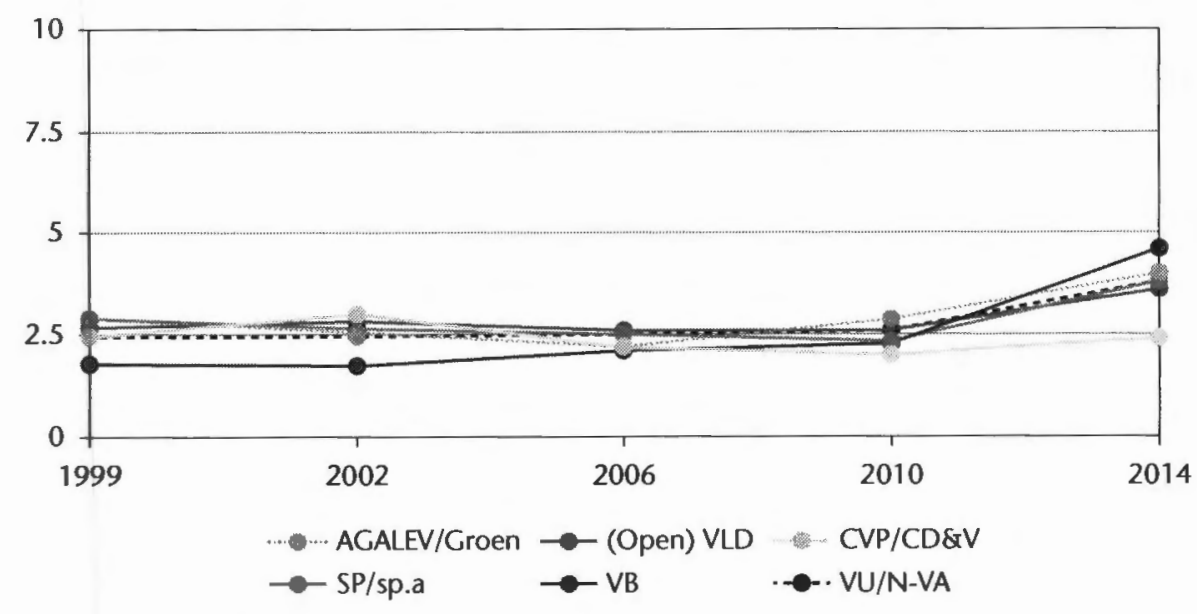

GRAFIEK 2, Belang van de EU voor politieke partijen (CHES-data) ${ }^{2}$. 
Vanuit het perspectief van het behalen van stemmen als partijdoel hebben partijen drijfveren om thema's te vermijden waarbij hun eigen positie sterk verschilt met die van het electoraat. Het heeft immers geen zin om in te zetten op een thema waarvan je weet dat het electoraat het daar niet mee eens is. Anderzijds gaan partijen waarvan de EU-positie dichter bij die van het electoraat ligt, sterker inzetten op dat thema. We kunnen dus verwachten dat die partijen niet alleen de EU meer naar voren gaan schuiven in hun partijprogramma's, maar ook dat zij bijgevolg nood zullen hebben aan meer interne EU-beleidsondersteuning. Hoe groter de (ideologische) afstand tussen partij en electoraat, hoe kleiner de kans dat partijen zullen europeaniseren, en vice versa.

Verscheidene auteurs hebben aangetoond dat over het algemeen het electoraat eurokritischer is dan de meeste partijen (Green-Pedersen, 2012; Marks \& Hooghe, 2009; Mattila \& Raunio, 2012). Grafieken 3 en 4 tonen respectievelijk de positie van de Vlaamse partijen vis-à-vis de EU en de houding van het Belgische electoraat tegenover de EU. Uit die grafieken blijkt een zekere discrepantie tussen de zeer uitgesproken pro-EU-positie van de meeste Vlaamse partijen en de groeiende onvrede met de EU bij de bevolking. In 2014 heeft minder dan de helft een positief beeld van de EU. Op basis daarvan kunnen we dus verwachten dat partijen met een meer gematigde positie of zelfs een eurokritische houding tegenover de EU, posities over de EU veel sterker naar voren zullen schuiven dan sterk eurofiele partijen. In het geval van Vlaanderen zouden dat dan voornamelijk het VB en in mindere mate de N-VA zijn. Hieruit volgt onze bijkomende hypothese:

H2.Partijen met een minder uitgesproken pro-EU-positie (N-VA, VB) zullen sterker reageren op Europese integratie dan andere partijen.

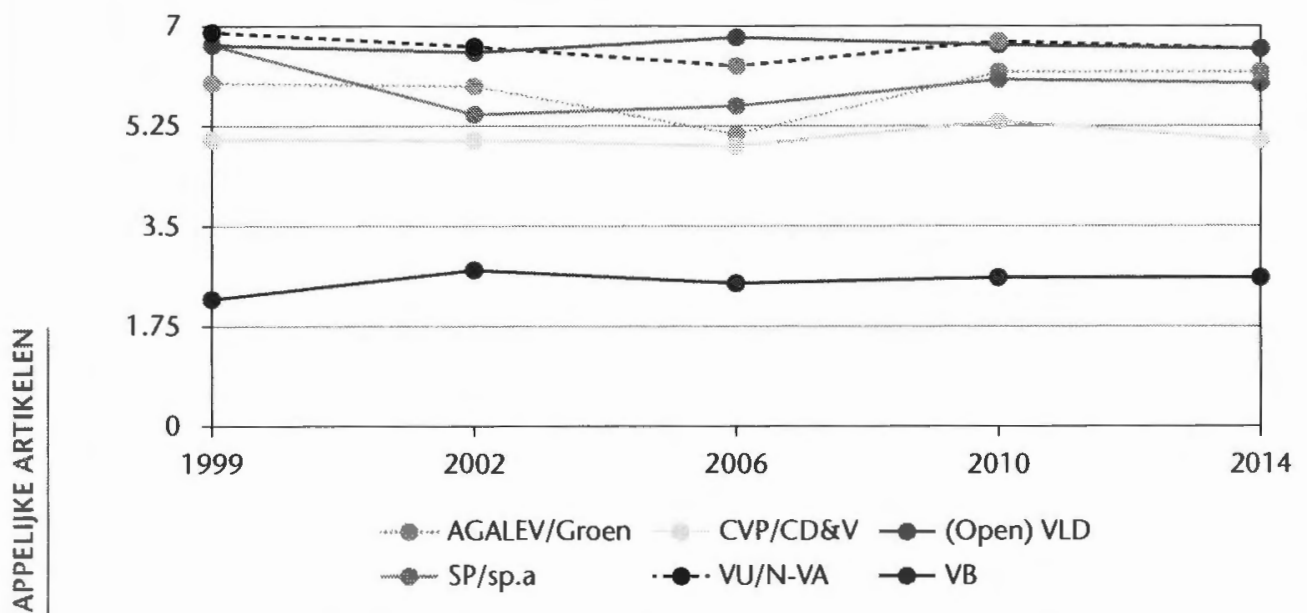

GRAFIEK 3. Positie Vlaamse partijen tegenover de EU (CHES-data) ${ }^{3}$. 


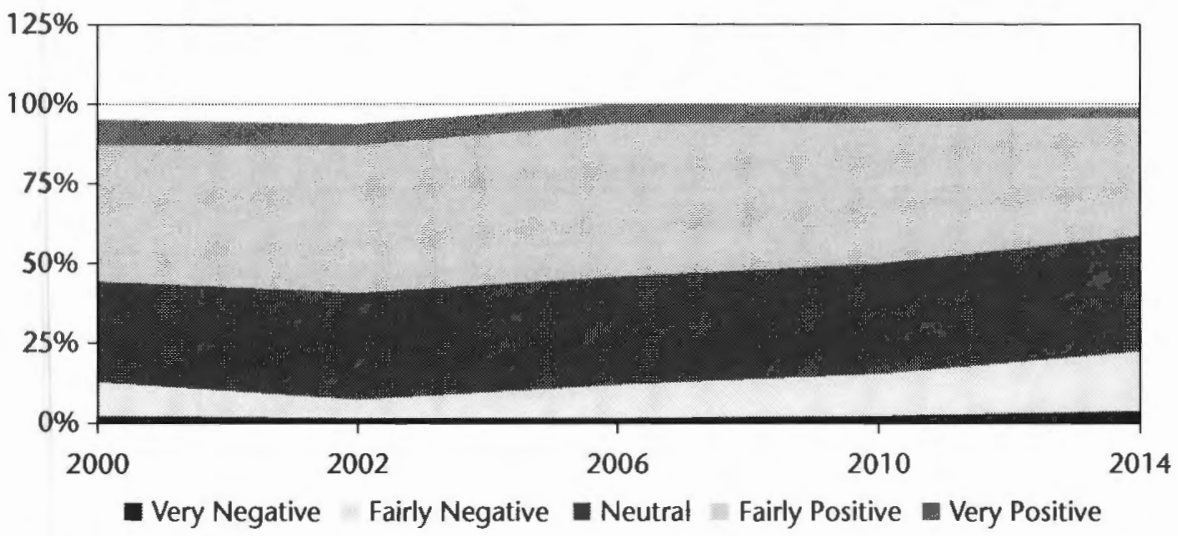

GRAFIEK 4. Publieke opinie tegenover de EU (data Eurobarometer) ${ }^{4}$.

Die twee hypothesen vormen het uitgangspunt van dit artikel. We verwachten, door de uitbreiding van de bevoegdheden van de EU en de stijging van het belang van de EU voor politieke partijen sinds 2010, een algemene stijging in europeanisering vanaf 2010, vooral, door de discrepantie tussen de EU-positie van de meeste partijen en die van het electoraat, bij N-VA en VB.

\subsection{Methode en dataverzameling}

Om de bovenstaande hypothesen te kunnen testen, bestudeert dit artikel de programmatische en organisatorische europeanisering van de Vlaamse partijen. Wat wordt hiermee bedoeld en hoe meten we dat?

Ten eerste analyseren we programmatische europeanisering. Dat verwijst naar de opname van de EU als thema in de partijprogramma's. Hoe meer de EU opgenomen wordt, hoe meer we kunnen spreken van programmatische europeanisering. Dergelijke programma's worden immers beschouwd als een goede indicator van zowel het beeld dat de partij naar buiten wil brengen, als de 'identiteit' van de partij (Harmel et al., 2016). De verwachting is dat hoe meer de EU aan belang wint binnen partijen, hoe meer de EU opgenomen zal worden als issue in politieke verkiezingsprogramma's.

Programmatische europeanisering wordt gemeten door te kijken naar enerzijds het al dan niet bestaan van EU-specifieke programma's of hoofdstukken in programma's, en anderzijds het aantal vermeldingen van Europese kwesties in de verkiezingsprogramma's. Dit artikel bestudeert hiervoor de federale verkiezingen van 1999 tot en met 2014 voor de zes Vlaamse partijen die in die periode een voortdurende parlementaire vertegenwoordiging hadden: VU/N-VA, CVP/CD\&V, (Open) Vld, SP/sp.a, AGALEV/Groen en VB. 
Bij de codering van de partijprogramma's werden alle zinnen opgenomen waarin verwijzingen naar de EU zijn gemaakt. ${ }^{5}$ Verwijzingen naar de euro als munteenheid of naar Europa als geografische eenheid werden buiten beschouwing gelaten. Daarnaast zijn er twee maatregelen genomen om de programma's vergelijkbaar te maken. Zo werden enkel de federale partijprogramma's opgenomen. Programma's die specifiek gericht zijn op Europese of regionale verkiezingen, werden buiten beschouwing gelaten. Bovendien werden bij samenvallende verkiezingen alle programmahoofdstukken die specifiek gericht zijn op een ander niveau dan het federale niveau, buiten beschouwing gelaten.

Ten tweede analyseren we organisatorische europeanisering. Dat duidt op de incorporatie in partijstructuren van zogenaamde 'EU-specialisten', zij die enkel of vooral rond de EU werken (Ladrech, 2007, p. 5). Hoe meer die specialisten een centrale functie in de partijstructuren hebben, hoe meer we kunnen spreken van organisatorische europeanisering. Concreet zijn dat de Europarlementsleden van de partij en de EUexperts die actief zijn in de studiedienst of partijwerkgroepen. Hierbij bestuderen we in de eerste plaats de politiek-strategische positie van Europarlementsleden binnen de partijwerking op basis van hun deelname in het partijbestuur en de partijraad, en hun rol in het uitstippelen van de Europese partijlijn. Daarnaast bekijken we de interne capaciteitsopbouw van de partijen met betrekking tot Europese zaken. Daarbij wordt nagegaan wat de positie van EU-specialisten is binnen de partij op basis van het bestaan van EU-werkgroepen en EU-specifieke medewerkers in de partijstudiedienst.

Die indicatoren worden gemeten op basis van drie databronnen. Ten eerste baseren wij ons op een analyse van de partijstatuten van de Vlaamse partijen die de formele positie van de EU-specialisten aangeeft. Ten tweede zijn er op verschillende moinenten tussen 2006 en 2011 semigestructureerde interviews afgenomen met de Europarlementsleden en internationale secretarissen van de Vlaamse partijen. In de interviews werd specifiek aandacht besteed aan het achterhalen van het belang van Europarlementsleden in het bepalen van de EU-partijlijn. Ten slotte is er in 2014 een digitale survey afgenomen onder de partijsecretarissen, waarin specifiek werd gepolst naar de positie van Europarlementsleden en EU-experts in de partij. Op basis van die analyse krijgt elke partij voor elk van de bestudeerde aspecten een score die wordt samengevoegd in een totaalscore op 10 voor organisatorische europeanisering.

\section{Programmatische europeanisering: de EU in partijprogramma's}

In dit deel onderzoeken we de mate waarin de EU opgenomen is in de federale partijprogramma's van de Vlaamse partijen: 1999, 2003, 2007, 2010 en 2014. Voor- 
eerst moet gezegd, dat in de voorbije decennia de regionale, federale en Europese verkiezingen in België geregeld tegelijkertijd plaatsvonden. In 2004 en 2009 vonden de regionale en Europese verkiezingen gelijktijdig plaats, en in 1999 en 2014 waren er simultane verkiezingen voor alle niveaus. In 2003, 2007 en 2010 vonden dan aparte federale verkiezingen plaats. Bovendien zien we dat in het geval van samenvallende verkiezingen niet alle partijen aparte programma's of hoofdstukken maken per beleidsniveau. In 1999 bijvoorbeeld had geen enkele partij een apart programma voor de Europese verkiezingen. Wel namen alle partijen een apart Europa-hoofdstuk op in hun algemene verkiezingsprogramma. Omdat dat uiteraard een impact heeft op de inhoud van de partijprogramma's, werden maatregelen genomen om die vergelijkbaar te maken (cf. supra).

Tabel 2 toont een overzicht van wanneer welke verkiezing plaatsvond en welke partij een apart EU-programma dan wel EU-hoofdstuk had. Daaruit valt af te leiden dat de Vlaamse partijen vooral in 2009 zeer actief waren om hun visie op de EU uit de doeken te doen. In 2014 heeft geen enkele partij nog een apart EU-programma gemaakt, en CD\&V en Open Vld hadden zelfs geen afzonderlijk hoofdstuk meer.

TABEL 2. Verkiezingen en EU-programma's en - hoofdstukken.

\begin{tabular}{|c|c|c|c|c|c|c|c|}
\hline Jaar & Niveau & $\begin{array}{l}\text { CVP/ } \\
\text { CD\&V }\end{array}$ & $\begin{array}{l}\text { (Open) } \\
\text { Vld }\end{array}$ & SP/sp.a & $\begin{array}{l}\text { AGALEV/ } \\
\text { Groen }\end{array}$ & VU/N-VA & VB \\
\hline 1999 & $\mathrm{VL} / \mathrm{FED} / \mathrm{EU}$ & H & H & H & H & $\mathrm{H}$ & $=\mathrm{H}$ \\
\hline 2003 & FED & n.v.t. & nyt. & n.v.t. & nut & n.t. & nut. \\
\hline 2004 & $\mathrm{VL} / \mathrm{EU}$ & $P$ & $x$ & $P$ & p & $x$ & $\mathrm{X}$ \\
\hline 2007 & FED & nvit & nivit. & n.vit. & nv.t. & n.v.t. & nvel. \\
\hline 2009 & VI/EU & $P$ & p. & $P$ & $\mathrm{P}$ & $H$ & $X$ \\
\hline 2010 & FED & n.v.t. & n.v.t. & n.v.t. & n.v.t. & novt & n.v.t. \\
\hline 2014 & VIFED/EU & $x$ & $x$ & H & $H$ & $H$ & $\mathrm{H}$ \\
\hline
\end{tabular}

n.v.t. = niet van toepassing; $\mathrm{P}=$ programma; $\mathrm{H}=$ hoofdstuk; $\mathrm{X}=$ hoofdstuk noch programma * Het EU-partijprogramma van Open Vld voor 2009 is het boek van Guy Verhofstadt, De weg uit de crisis: hoe Europa de wereld kan redden.

Weerspiegelt zich dat wanneer we kijken naar het aantal referenties die gemaakt worden naar de EU in de verkiezingsprogramma's van de Vlaamse partijen? Grafiek 5 toont de resultaten van de codering van de partijprogramma's voor de federale verkiezingen van 1999 tot 2014, die in 1999 en 2014 samenvielen met de regionale en Europese verkiezingen. Hierbij valt op dat in 1999 de Vlaamse partijen opvallend meer verwijzingen maakten naar de EU dan tijdens het eerste decennium van de 21ste eeuw. Pas in 2014 zitten sommige partijen weer rond het niveau van 2003. Waar sp.a in 2014 op dezelfde lijn blijft als in 2010, houden Open Vld en CD\&V er minder referenties op na. Opvallend is vooral de scherpe stijging bij de Vlaamsnationalisten en extreemrechts in de aanloop naar de verkiezingen van 2014. 


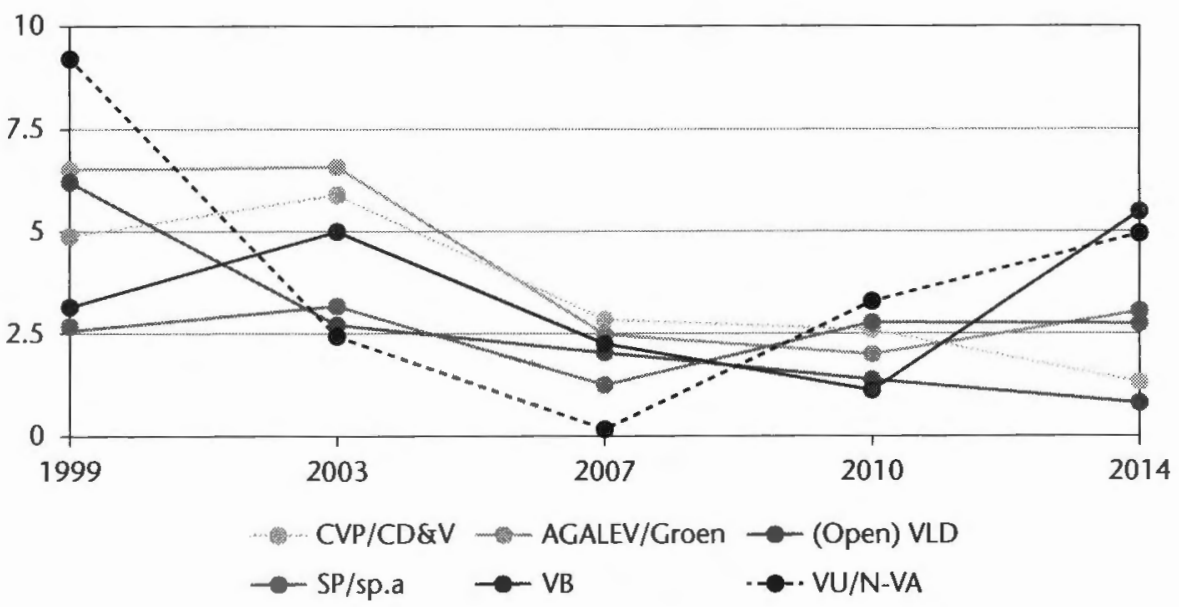

GRAFIEK 5. Opname EU in partijprogramma's (in procent van totale tekst).

\section{Organisatorische europeanisering: incorporatie van de EU in de partij}

Om organisatorische europeanisering te analyseren, bekijken we in welke mate de EU geïncorporeerd is zowel op het politiek-strategische niveau als op het niveau van de beleidsondersteuning van de partijen. Concreet kijken we naar de positie van Europarlementsleden en EU-experts in de partij. Het eerste meten we aan de hand van de deelname van Europarlementsleden aan het partijbestuur en de partijraad, alsook hun algemene invloed op de EU-partijlijn. Het tweede meten we aan de hand van het bestaan van EU-werkgroepen binnen de partij en de aanwezigheid van EU-specifieke medewerkers in de partijstudiedienst.

\subsection{De positie van Europarlementsleden}

Wat het partijbestuur betreft, begonnen vanaf het begin van de jaren 1970 alle partijen in België de Europarlementsleden systematisch in hun bestuur op te nemen. De laatste Vlaamse partij om haar Europarlementsleden op te nemen in het bestuur, was het toenmalige Agalev in 1996 (Deschouwer \& Van Assche, 2003). Toch is lidmaatschap van het partijbestuur niet overal automatisch open voor Europarlementsleden. Bij sp.a wordt lidmaatschap toegekend op basis van interne verkiezingen. Bij het VB is het afhankelijk van het uitoefenen van andere 'belangrijke' 
functies binnen de partij. CD\&V laat dan weer enkel het hoofd van haar delegatie in het Europees Parlement toe tot het bestuur. Bij de overige partijen zijn de Europarlementsleden wel allemaal automatisch lid.

Wat de partijraad betreft, zijn in theorie Europarlementsleden in alle partijen automatisch lid, aangezien alle verkozenen sowieso tot de partijraad behoren. Toch blijkt dat de facto niet altijd zo te zijn. Bij CD\&V worden Europarlementsleden wederom vertegenwoordigd door het hoofd van de delegatie in het Europees Parlement, bij sp.a hebben zij geen stemrecht, en bij VB en Open Vld staan zij amper op de lijst van de aanwezigen. Enkel bij Groen en N-VA lijken zij volwaardig en actief lid.

Wat zegt dat over de rol die Europarlementsleden spelen in het uitstippelen van de Europese partijlijn? Afgaand op hun formele positie, kunnen we stellen dat zij een vrij uitgebreide rol spelen bij het uittekenen van de Europese partijlijn. Toch zien we in de praktijk heel wat verschillen tussen de partijen. Waar Groen en Open Vld aangeven dat hun Europarlementsleden zeer sterk worden betrokken bij het bepalen van de Europese lijn, worden zij bij N-VA of VB veel meer op zichzelf gelaten. Sp.a geeft aan dat hun Europarlementsleden voornamelijk worden geconsulteerd wanneer het hun specifieke beleidsdomein aangaat. In het geval van CD\&V wordt de officiële lijn voorbereid door een werkgroep ad hoc; de partijleiding beslist dan later met de input van Europarlementsleden.

De posities van Europarlementsleden kregen als volgt een score van 0 tot 2 toegekend:

- Wat het partijbestuur betreft, krijgen de partijen waarbij de Europarlementsleden automatisch lid zijn, een score 2 . Partijen waarbij het lidmaatschap afhangt van verkiezingen of Europarlementsleden andere functies krijgen, of waarbij dat gebeurt via delegatie, krijgen een score 1. Partijen waarbij de Europarlementsleden in de praktijk helemaal geen lid zijn, krijgen een score 0 .

- Wat de partijraad betreft, krijgen partijen waarbij de Europarlementsleden volwaardig lid zijn, een score van 2 . Partijen waarbij zij vertegenwoordigd worden, krijgen een score van 1 , en partijen waarbij zij geen stemrecht hebben, krijgen een score 0 .

- Wat de invloed op de EU-partijlijn betreft, krijgen partijen waarbij de Europarlementsleden een grote invloed hebben, een score 2 ; hebben ze maar een beperkte rol, dan krijgen ze een score 1. Partijen waarbij de Europarlementsleden zelf de partijlijn uitzetten, krijgen een score 0 , aangezien dat duidt op een gebrek aan incorporatie van de EU in de rest van de partij.

Dat brengt ons tot een score per partij, zoals te zien is in Tabel 3. Algemeen hebben de Europarlementsleden geen slechte positie in de partijstructuren. Op sp.a en VB na hebben alle partijen een score van minsten vier op zes. De stijgende lijn bij Open Vld heeft vooral te maken met hun sterkere positie in de partijraad. Bij 
Groen en N-VA zit de stijging in een sterkere appreciatie van hun rol in het bepalen van de Europese partijlijn. De variatie binnen sp.a is te wijten aan een wisselende deelname aan de partijraad en het partijbestuur.

TABEL 3. Positie van Europarlementsleden (score op 6).

\begin{tabular}{lcccccc}
\hline & CVP/CD\&V & (Open) Vld & SP/sp.a & $\begin{array}{c}\text { AGALEV/ } \\
\text { Groen }\end{array}$ & VU/N-VA & VB \\
\hline 2003 & 4 & 3 & 4 & 4 & 4 & 1 \\
2006 & 4 & 4 & 5 & 6 & 4 & 2 \\
2010 & 4 & 3 & 5 & 6 & 4 & 2 \\
2014 & 4 & 3 & 6 & 6 & 5 & 2 \\
\hline
\end{tabular}

\subsection{Positie van $E U$-specialisten}

Wat de studiediensten betreft, zien we dat waar de meeste partijen tot 2006 nog aangaven dat de EU van gering belang is binnen de studiedienst, tegen 2010 de helft van de partijen de EU op een of andere manier hadden geïncorporeerd en dat tegen 2014 nagenoeg alle partijstudiediensten de EU een belangrijk thema vonden. Enkel de studiedienst van VB heeft geen specifieke EU-expert. CD\&V, Groen en sp.a hebben elk minstens één EU-expert in de studiedienst, en in de studiediensten van Open Vld en N-VA volgt iedereen het EU-beleid op per beleidsdomein. Op het VB na hebben alle partijen dus een zekere mate van EU-expertise in de studiedienst, en die medewerkers staan vaak in contact met iedereen in de partij die iets met Europa te maken heeft.

Partijen volgen het beleid op, niet alleen via de studiedienst maar vaak ook via specifieke werkgroepen. Opnieuw zien we een sterke europeanisering tegen 2014. In 2010 hadden veel partijen nog geen werkgroepen rond Europa, of enkel werkgroepen ad hoc, terwijl in 2014 de meeste partijen op een of andere manier op geregelde basis werkgroepen organiseerden. Zowel sp.a, Groen als N-VA hebben een permanente werkgroep Europa, al heeft N-VA die pas na de verkiezingen van 2014 opgericht. Bij CD\&V komt de EU-werkgroep ad hoc samen. Open Vld heeft dan weer geen vaste werkgroep (meer), maar organiseert samenkomsten ad hoc. Enkel VB laat de EU-werking compleet over aan haar Europarlementslid.

Voor de positie van EU-experts werd een score van 0 tot 3 als volgt toegekend:

- Wat de studiediensten betreft, hebben partijen die de EU breed per beleidsdomein opvolgen, een score 3 gekregen. Partijen met EU-specifieke medewerkers hebben een score 2 gekregen. Partijen waarvan de medewerkers niet systema- 
tisch binnen hun eigen domein de EU opvolgen maar enkel wanneer er een nationaal belang is, kregen een score 1. Partijen die de EU niet of amper belangrijk achten, krijgen een score 0 .

- Wat de werkgroepen betreft, hebben de partijen met permanente EU-werkgroepen een score 3 gekregen. Partijen met vaste bijeenkomsten van werkgroepen krijgen een score 2, en die met werkgroepen ad hoc een score van 1. Partijen die geen of weinig EU-werkgroepen organiseren, krijgen een score 0.

Dat brengt ons tot een score per partij, zoals te zien is in Tabel 4. Twee zaken vallen op. Ten eerste is er de sterke stijging bij veel partijen tussen 2003 en 2014 . Alle partijen hadden in 2003 slechts een beperkte capaciteit voor EU-beleidsondersteuning. Toch zien we dat in 2014 alle partijen, op N-VA en VB na, een zeer sterke capaciteit hebben uitgebouwd. Ten tweede valt op dat er een zeer sterk verschil bestaat tussen N-VA en VB enerzijds en de andere partijen anderzijds. N-VA en VB blijken amper of niet geïnvesteerd te hebben in interne EU-expertise.

TABEL 4. Positie van EU-experts (score op 6).

\begin{tabular}{lcccccc}
\hline & CVP/CD\&V & SP/sp.a & (Open) VLD & $\begin{array}{c}\text { AGALEV/ } \\
\text { Groen }\end{array}$ & VU/N-VA & VB \\
\hline 2003 & 3 & 0 & 0 & 0 & 0 & 0 \\
2006 & 2 & 2 & 2 & 2 & 0 & 1 \\
2010 & 2 & 2 & 2 & 4 & 0 & 0 \\
2014 & 5 & 5 & 4 & 5 & 1 & 0 \\
\hline
\end{tabular}

De scores voor beide aspecten kunnen we samenbrengen en verrekenen tot een totaalscore op 10 voor organisatorische europeanisering per partij. Grafiek 6 toont het resultaat van die oefening. Wanneer we de resultaten naast elkaar leggen, vallen twee zaken op. Ten eerste is het opmerkelijk dat de partijen waarbij de positie van de Europarlementsleden redelijk stabiel is gebleven, vooral meer hebben geïnvesteerd in het vergaren van EU-expertise via experts in werkgroepen en de studiedienst. Waar de score voor de positie van Europarlementsleden tussen 2003 en 2014 gemiddeld voor alle partijen met slechts één punt gestegen is, is de positie van EU-experts met 2,8 punten gestegen.

Ten tweede is de stijging tussen 2003 en 2014 voor alle partijen behalve VB opvallend. VB buiten beschouwing gelaten, hebben de Vlaamse partijen in 2003 een gemiddelde score van 3,7 en in 2014 een gemiddelde score van 7,3. Tussen 2003 en 2006 zien we een gemiddelde stijging over alle partijen (VB incluis) van 1,8. Tussen 2006 en 2010 is er een stagnatie (gemiddelde stijging 0). Tussen 2006 en 2014 zien we een gemiddelde stijging van 1,7. 


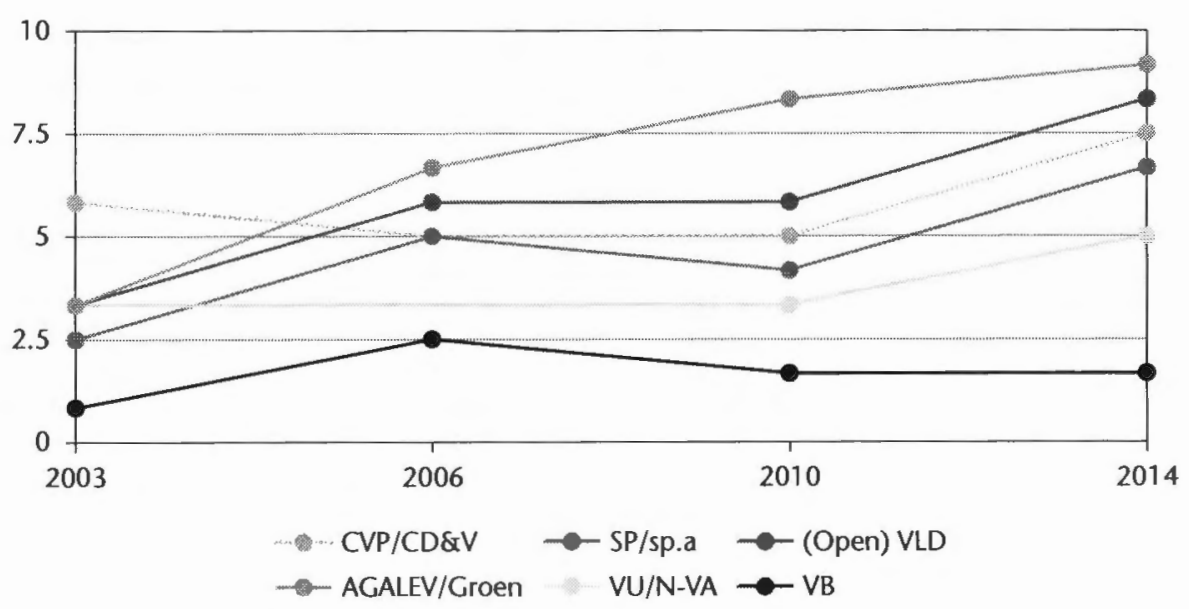

GRAFIEK 6. Incorporatie van de EU in partijorganisatie (score op 10).

\section{Conclusie en discussie}

De europeanisering van nationale partijen was voor Vlaanderen tot nu toe slechts anekdotisch onderzocht. Dit artikel heeft gepoogd om die leemte in de literatuur weg te werken door de organisatorische en programmatische europeanisering van de Vlaamse partijen te bestuderen tussen 1999 en 2014. De algemene verwachting was dat de europeanisering zou toenemen naarmate de partijen meer belang hechtten aan de EU, en dan vooral voor meer eurokritische partijen.

Kunnen we op basis van de bovenstaande analyse die verwachtingen bevestigen? Het antwoord hierop luidt 'ja, maar'. Wat de eerste hypothese betreft, zien we inderdaad een toename in de europeanisering van partijen na 2010, zowel op programmatisch als op organisatorisch vlak. Toch zijn er enkele zaken die niet verklaard kunnen worden op basis van een stijging in het belang dat partijen hechten aan de EU. Ten eerste is de stijging na 2010 zeker niet voor alle partijen waar. Het aantal EU-referenties in de programma's van VB, CD\&V en Open Vld vermindert zelfs na 2010, en bij sp.a zien we een stagnatie. Ook de organisatorische europeanisering van het VB blijft op dezelfde lijn na 2010. Ten tweede valt het zeer hoge aantal referenties naar de EU in de partijprogramma's van 1999 niet binnen de theoretische verwachtingen, en dat geldt evenzeer voor de stijging in organisatorische europeanisering tussen 2003 en 2006. Ten slotte ligt de opvallend sterke stijging in het programma van de N-VA, die volgens de CHES-data het minst van alle partijen belang hecht aan de EU, buiten die verwachtingen. 
Het antwoord op de tweede hypothese kan hulp bieden bij het verklaren van die resultaten. Op beide aspecten van europeanisering zien we namelijk een duidelijke scheiding tussen enerzijds CD\&V, Open Vld, sp.a en Groen, en anderzijds N-VA en VB. Waar N-VA en VB in 2014 een veel hoger aantal referenties aan de EU maken dan de andere partijen, zien we dat ze het minst hebben ingezet op incorporatie van de EU in de partijorganisatie. Niettemin liggen de uiteenlopende resultaten wat de partijprogramma's betreft, voor N-VA en VB vis-à-vis de andere partijen in lijn met de verwachtingen op basis van hun positie ten aanzien van de EU. Wat de partijorganisatie betreft, zijn de resultaten echter het compleet omgekeerde van wat werd verwacht: N-VA en VB zijn juist het minst geëuropeaniseerd.

Er zijn met andere woorden nog andere mechanismen aan het werk bij de programmatische en organisatorische europeanisering, maar ook bij de EU-positie van partijen. Het feit dat de meeste partijen hun organisatiestructuren hebben aangepast, wijst erop dat ze zich wel degelijk bewust zijn van het groeiende belang van Europa als besluitvormingsniveau. De verschillen met de programmatische europeanisering maken echter duidelijk, dat het vooral de eurokritische partijen zijn die Europa als thema bij de verkiezingen willen uitspelen. De traditionele partijen zijn eerder terughoudend om in hun verkiezingsprogramma's veel aandacht te schenken aan de EU. Door hun inbedding in de Europese mainstream is het ook niet verbazend dat ze niet happig zijn om van de EU een sterk gepolitiseerd politiek issue te maken. In de voorbije legislatuur van het Europees Parlement hebben de drie traditionele partijen bijvoorbeeld overweldigend samengewerkt in de zogenaamde 'super grand coalition' (Hix, 2014, p. 4). Opvallend is ook de paradoxale europeanisering van het VB, volgens data van de CHES de enige eurokritische partij in Vlaanderen, en in mindere mate ook van de N-VA. Hoewel ze zeer sterk investeren in de politisering van de EU, nemen ze de EU amper op in hun partijstructuren. Dat kan wijzen op een zeer specifieke evolutie van eurokritische partijen, namelijk politisering zonder intern het belang van de EU te erkennen. Dat alles duidt op het belang om te gaan kijken naar partijcompetitie als interveniërende variabele die variatie in aanpassing vormgeeft.

De traditionele pro-EU-partijen lijken dus voornamelijk te handelen vanuit hun beleidsdoelen en in mindere mate vanuit het behalen van stemmen. Ze investeren immers sterk in interne EU-expertise, maar spelen de EU minder uit in hun partijprogramma's. Een diepere analyse van de partijprogramma's moet uitmaken of die partijen in hun programma's ook meer naar het EU-beleid verwijzen en minder naar de EU op zich. De meer eurokritische partijen lijken dan weer eerder te handelen vanuit hun doel om stemmen te halen, door de EU fel uit te spelen in hun programma's, maar door hun lagere incorporatie van de EU in de partijorganisatie lijken ze minder te handelen vanuit beleidsdoelen. Bij N-VA kan dat deels verklaard worden door het feit dat ze pas in 2010 haar studiedienst substantieel heeft 
uitgebreid. Bovendien geeft die partij in de survey aan dat ze fel heeft geïnvesteerd in de uitbreiding van haar EU-expertise na de verkiezingen van 2014.

Kortom, de analyse doet uitschijnen dat de meeste partijen het belang van de EU onderkennen, maar vooral de meer eurokritische partijen de EU ook effectief politiseren in hun partijprogramma's. Meer onderzoek is echter nodig om de lage salience en de lange non-europeanisering van de Vlaamse partijen te verklaren. Toch doen we hier al een voorzichtige poging. Op het eerste gezicht zijn er twee mogelijke verklaringen: de hardnekkige focus op binnenlandse politiek in België en de langdurige pro-Europa-consensus onder de Belgische bevolking.

Vooreerst is de Belgische politiek lange tijd in beslag genomen door een binnenlandse politieke agenda die voornamelijk draaide rond constitutionele hervormingen. Daardoor was er op de politieke agenda weinig ruimte voor andere thema's. Hier komt bij dat partijen helemaal geen incentives hadden om het Europese thema sterk naar voren te schuiven. Door de brede pro-integratieconsensus (Fraussen \& Dejaeghere, 2011) bood Europa helemaal geen opportuniteit voor electorale winst. Ook had het VB de EU niet nodig om zichzelf op de politieke markt te profileren. Dat deden ze al met hun kernthema's migratie en Vlaamse onafhankelijkheid. In België zat de EU dus min of meer in een vicieuze cirkel van lage salience.

Onze analyse wijst echter uit dat er meer aan de hand is dan alleen het feit dat Vlaamse partijen lange tijd weinig belang aan de EU hebben gehecht. De stijging in salience tussen 2010 en 2014 had immers geen overweldigende impact op de europeanisering van de Vlaamse partijen. Om die evolutie beter te begrijpen, moet toekomstig onderzoek daarom verder gaan kijken naar de impact op het gehele partijsysteem. Ook dienen andere interveniërende variabelen onderzocht te worden. De literatuur reikt er een aantal aan: de oppositiestatus van een partij (van de Wardt, 2015), de plaatsing op de as links-rechts (Green-Pedersen, 2012), de grootte van de partij (Netjes \& Binnema, 2007) of de ideologische reputatie van de partij (Marks \& Hooghe, 2009). Die factoren werden in dit artikel niet opgenomen, maar verdienen het om verder onderzocht te worden teneinde de europeanisering van de Vlaamse partijen nader te verklaren.

\section{Noten}

1. Analyse op basis van data van de Chapel Hill Expert Surveys: 0 staat voor 'completely united' en 10 voor 'extremely divided'.

2. Analyse op basis van data van de Chapel Hill Expert Surveys. Bij elke meting nemen ze een survey af onder nationale experts waarbij zij hun vragen om partijen uit hun land een score te geven op verschillende thema's. Wat het belang van de EU betreft, 
dienden deze experts elke partij een score van 0 tot 10 te geven, waarbij 0 staat voor 'no importance, never mentioned' en 10 voor 'most important issue'. Die scores worden gegeven op basis van onder meer politieke media-analyses.

3. Analyse op basis van data van de Chapel Hill Expert Surveys: 1 staat voor 'strongly opposed' en 7 voor 'strongly in favour'.

4. Analyse op basis van data van de Eurobarometer. Grafiek 3 toont de resultaten voor de vraag: 'In general, does the EU conjure up for you a very positive, fairly positive, neutral, fairly negative or very negative image?'

5. Wij volgen hierbij Däubler et al. (2012), die stellen dat natuurlijke zinnen een betere maatstaf zijn voor codering dan de gebruikelijke methode van 'quasi-zinnen'.

\section{Bibliografie}

Allern, E. H., \& Saglie, J. (2012). Inside the black box: Parties as multi-level organisations in a unitary state. West European Politics, 35(5), 947-970.

Benoit, K., \& Laver, M. (2006). Party policy in modern democracy. London: Routledge.

Biezen, I. van, \& Molenaar, F. (2012). The Europeanisation of party politics? Competing regulatory paradigms at the supranational level. West European Politics, 35(3), 632-656.

Börzel, T. A. (2005). Europeanization: How the European Union interacts with its member states. In S. Bulmer \& C. Lequesne (Eds.), The Member States of the European Union (pp. 45-69). Oxford: Oxford University Press.

Bulmer, S. (2006). Theorizing Europeanization. In P. Graziano \& M. Vink (Eds.), Theorizing Europeanization: New research agendas (pp. 46-58). Basingstoke: Palgrave Macmillan.

Carmines, E. G., \& Stimson, J. A. (1986). On the structure and sequence of issue evolution. The American Political Science Review, 80(3), 901-920.

Carter, E., Luther, K. R., \& Poguntke, T. (2007). European Integration and internal party dynamics. In E. Carter, T. Poguntke, N. Aylott, R. Ladrech, \& K. R. Luther (Eds.), Europeanization and national political parties: Adaptation and power (pp. 1-27). Abingdon: Routledge.

Dardanelli, P. (2011). Europeanisation and federalisation in Belgium: A comparative study of the Flemish parties. Political Studies Association Annual Conference, Londen, april 2011.

Däubler, T., Benoit, K., Mikhaylov, S., \& Laver, M. (2012). Natural sentences as valid units for coded political texts. British Journal of Political Science, 42(4), 937-951. 
Deschouwer, K. (2009). The politics of Belgium. Governing a divided society. Basingstoke: Palgrave Macmillan.

Deschouwer, K., \& Van Assche, M. (2003). De europeanisering van de Belgische partijen. Res Publica, 45(1), 121-142.

Dinan, D. (2010). Ever closer union. An introduction to European integration. Basingstoke: Palgrave Macmillan.

Dumont, P., \& De Winter, L. (2006). Do Belgian parties undermine the democratic chain of delegation? West European Politics, 29(5), 957-976.

Eijk, C. van der, \& Franklin, M. N. (2004). Potential for contestation on European matters at national elections in Europe. In G. Marks \& M. R. Steenbergen (Eds.), European integration and political conflict (pp. 33-50). Cambridge: Cambridge University Press.

Fraussen, B., \& Dejaeghere, Y. (2011). Belgian parties, interest groups, media and public opinion and the presidency: A non-issue for non-state actors? In S. Van Hecke \& P. Bursens (Eds.), Readjusting the council presidency: Belgian leadership in the EU (pp. 79-100). Brussels: Academic and Scientific Publishers.

Green-Pedersen, C. (2012). A giant fast asleep? Party incentives and the politicisation of European Integration. Political Studies, 60(1), 115-130.

Harmel, R., Tan, A. C., Janda, K., \& Smith, J. M. (2016). Manifestos and the 'two faces' of parties: Addressing both members and voters with one document. Party Politics, Published online June 6.

Hecke, S. van. (2009). Europeanization and political parties: The Partido Popular and its transnational relations with the European People's Party. Journal of International Iberian Studies, 22(2), 109-124

Hix, S. (2014). Why the 2014 European elections matter: Ten key votes in the 2009-2013 European Parliament. European Policy Analysis, (15), 1-16.

Hix, S., \& Hoyland, B. (2011). The political system of the European Union. Basingstoke: Paigrave Macmillan.

Kriesi, H. (2007). The role of European integration in national election campaigns. European Union Politics, 8(1), 83-108.

Ladrech, R. (2002). Europeanization and political parties: Towards a framework for analysis. Party Politics, 8(4), 389-403.

Ladrech, R. (2007). National political parties and European governance: The consequences of 'missing in action'. West European Politics, 30(5), 945-960.

Ladrech, R. (2012). Party change and Europeanisation: Elements of an integrated approach. West European Politics, 35(3), 574-588.

Mair, P. (2000). The limited impact of Europe on national party systems. West European Politics, 23(4), 27-51.

Mair, P. (2007). Political parties and party systems. In P. Graziano \& M. Vink (Eds.), Europeanization: New research agendas (pp. 154-166). Basingstoke: Palgrave Macmillan. 
Marks, G., \& Hooghe, L. (2009). A postfunctionalist theory of European integration: From permissive consensus to constraining dissensus. British Journal of Political Science, 39(1), 1-23.

Mattila, M., \& Raunio, T. (2012). Drifting further apart: National parties and their electorates on the EU dimension. West European Politics, 35(3), 589-606.

Netjes, C. E., \& Binnema, H. A. (2007). The salience of the European integration issue: Three data sources compared. Electoral Studies, 26(1), 39-49.

Pennings, P. (2006). An empirical analysis of the Europeanization of national party manifestos, 1960-2003. European Union Politics, 7(2), 257-270.

Raunio, T. (2000). Losing independence or finally gaining recognition? Contacts between MEPs and national parties. Party Politics, 6(2), 211-223.

Raunio, T. (2002). Why European integration increases leadership autonomy within political parties. Party Politics, 8(4), 405-422.

Sloam, J. (2004). The European policy of the German social democrats: Interpreting a changing world. Basingstoke: Palgrave Macmillan.

Vries, C. E. de. (2007). Sleeping giant: Fact or fairytale? How European integration affects national elections. European Union Politics, 8(3), 363-385.

Vries, C. E. de. (2010). EU issue voting: Asset or liability? How European integration affects parties' electoral fortunes. European Union Politics, 11(1), 89-117.

Wardt, M. van de. (2015). Desperate needs, desperate deeds: Why Mainstream parties respond to the issues of niche parties. West European Politics, 38(1), 93-122. 